\title{
Sexual Pain Disorder with Anxiety and Depressive Psychopathology as Complication: A Case-Report
}

\author{
AMEERAH ADEELAH MA, KANIT TD, HATTA S \\ Department of Psychiatry, Faculty of Medicine, Universiti Kebangsaan Malaysia Medical \\ Centre, Jalan Yaacob Latif, Bandar Tun Razak, 56000 Cheras, Kuala Lumpur, Malaysia.
}

\begin{abstract}
ABSTRAK
Vaginismus adalah disfungsi seksual yang disebabkan oleh pengecutan otototot faraj yang menyebabkan kemasukan zakar semasa hubungan seks amat sukar, atau mustahil berlaku. la sering diiringi tekanan perasaan yang ketara. Di dalam kebanyakan kes, ia berkait-rapat dengan perasaan ketakutan melampau yang meneruskan hayat dan sifat penyakit ini. Kami melaporkan kes vaginismus primer yang menyebabkan komplikasi psikiatri jenis kerisauan-kemurungan lalu mencadangkan pendekatan perawatan holistik yang merangkumi pendekatan tingkah-laku dan psikofarmakologi. Rawatan permasalahan psikiatri yang berkaitrapat dengan vaginismus harus terlebih dahulu ditangani, secara baik bersamasama rawatan kepada vaginismus. Kombinasi bersepadu pendekatan tingkah-laku, psikologi dan farmakologi amat penting bagi memastikan prognosis rawatan adalah baik.
\end{abstract}

Kata kunci: vaginismus, primer, kerisauan-kemurungan

\begin{abstract}
Vaginismus is a sexual dysfunction which results from vaginal musculature spasm and makes the penetration almost impossible. It is commonly associated with significant emotional distress. On several occasions, fear of pain during sexual intercourse may perpetuate the sexual dysfunction. We report a case of primary vaginismus that was associated with psychiatric squeale of anxiety and depression psychopathology. It suggests that psychological problems related to a mentalhealth problem in vaginismus should be dealt adequately for a holistic approach. A combination of behavioural, psychological and pharmacological treatment is important to ensure a good prognosis outcome.
\end{abstract}

Keywords: vaginismus, primary, anxiety-depression

Address for correspondence and reprint requests: Hatta Sidi, Department of Psychiatry, Faculty of Medicine, Universiti Kebangsaan Malaysia Medical Centre, Jalan Yaacob Latif, Bandar Tun Razak, 56000 Cheras, Kuala Lumpur, Malaysia. Tel: +603-91456142 Fax: +603-91456681 Email: hattasidi@hotmail.com 


\section{INTRODUCTION}

Genito-pelvic penetration disorder is now inluded in DSM-5 and represents the merging concept of vaginismus and dyspareunia, which are highly correlated (Ishak \& Tobia 2013). In the previous classification of DSM-IVTR (American Psychiatric Association 2000), vaginismus is classified as a sexual dysfunction and is included in sexual pain disorder category. Vaginismus is defined as, "recurrent or persistent involuntary spasm of the musculature of the outer third of the vagina that interferes with sexual intercourse" and the muscle spasm is described as readily observable and in some cases, as 'so severe or prolonged as to cause pain'. In contrast, gynecological examinations have found that vaginal or pelvic spasm occurs only in few cases in vaginismic patients (Reissing et al. 2014). Primary vaginismus occurs when penetrative sexual intercourse had never happened and this is referred as 'unconsummated marriage'. We highlight a case of young Malay women with significant anxiety and depressive psychopathology, secondary to her primary vaginismus.

\section{CASE REPORT}

Madam Z, a 31-year-old Malay female, Assistant Auditor, married for two and half years, presented with painful sexual intercourse since she got married two and half years ago. Patient was first referred to us by gynaecology team on $22^{\text {nd }}$ December 2014, which was 6 months ago for further management of her complaint. She was previously well and unaware of her condition until she got married two and half years ago. She first experienced the pain during the first time she and her husband having sexual activity. Initial stage of the sexual activity was going on smoothly. She was aroused after half an hour of foreplay, which usually involved kissing over face, neck and breast, followed by biting over neck, arm and thigh. Then, the husband inserted his tongue into patient's vagina. Once both of them aroused, husband then positioned her for penetration process. However, upon an attempt of penile penetration, she started to feel the pain when husband's penis touched the surface of her vagina. She described the pain as burning sensation and as if pain where her skin was tearing. Husband then stopped the attempt after he saw her in much pain. She then noted that there was minimal blood spotting on the bed sheet. She denied her vagina was too dry during that attempt. In fact, her vagina was lubricated well prior to penetration of husband's penis. Although an attempt of penile penetration and fingering caused patient to have pain, on the other hand, husband managed to insert half of his tongue in her vagina without patient experiencing any pain. She also denied having any marital conflict or argument with husband prior to that. Following that, she experienced pain over her vagina for two to three days, especially during urination and also whenever she wanted to wash her genitalia.

They still were having sexual activity regularly about 2-3 times/week. Whenever they had the sexual activity, her husband will still attempted for penile penetration but each time he 
attempted for it, patient had the pain. Pain worsened if the husband continued to attempt for it. Husband usually stopped the attempt immediately as he felt pity for her. Even though the husband stoped the attempt, the pain did not go away. Although their sexual activity was disturbed, husband never asked her to masturbate for him or doing oral sex, but there was time when he would fulfill his orgasm by rubbing his penis over patient's abdomen and ejaculate over it. Sometimes, husband spread the semen over her vagina with the hope that the sperm may penetrate through her vagina. She still had sexual desires and her libido was maintained. She still got aroused and excited if her husband approached her. She never avoided having sex or refused sex. At times, she was the one who started to approach her husband. Both of them never gave up in attempting for penile penetration, even though it eventually failed. She also complained that she was a bit slow to get aroused as compared to her husband. She claimed usually she required half an hour of foreplay before she got aroused. In addition, she also imagined someone else doing sex like activity in movies for her to speed up her sexual arousal parallel with her husband. She claimed she would get aroused faster if she is on top of her husband. She noticed her vagina would get lubricated easily whenever she was excited. On the other hand, her husband did not have any problem with sexual arousal. He was able to achieve penile erection after five minutes of foreplay, and able to maintain it. She was not satisfied with their sexual activity, but she could not help it because of intolerable pain but she did not feel sexual activity was a burden to her due to her limitation. She also felt pity for her husband and wished she could satisfy him. Lately, for the past 2 weeks, she had felt anxious about her sexual performance. She had occasional palpitations, feelings of unable to relax and difficulty in concentration. She also had anxiety symptoms like jittery feeling when thinking of to let her husband to penetrate her when both were ready for sex. She had the fear that the husband might get fed up or give up on her despite her husband being very supportive of her. She also had a low mood as she would be "not a good enough wife," as she was depriving her husband from sexual satisfaction. She had feeling of anhedonia, negative thinking about her capacity of a good wife and sometimes felt worthlessness. She denied any deterioration of function at work. She denied history of being harassed sexually or being molested either during present or even during childhood. There was also no history of direct trauma to her genitalia. There was no history of fall or injury.

Patient attained menarche at age of 14 years. Her menses usually lasted for 7 days, and her menstrual cycle was regular within 28 to 30 days. She only experienced mild dysmenorrhea during first day of menses. Her menstrual flow was normal. There was no menorrhagia nor blood clots. She usually used 5 pads/ day. The family tree was summarized (Figure 1).

Patient was $9^{\text {th }}$ out of 10 siblings. She had 4 brothers, 7 sisters, and 1 stepsister. Her father passed away at age 


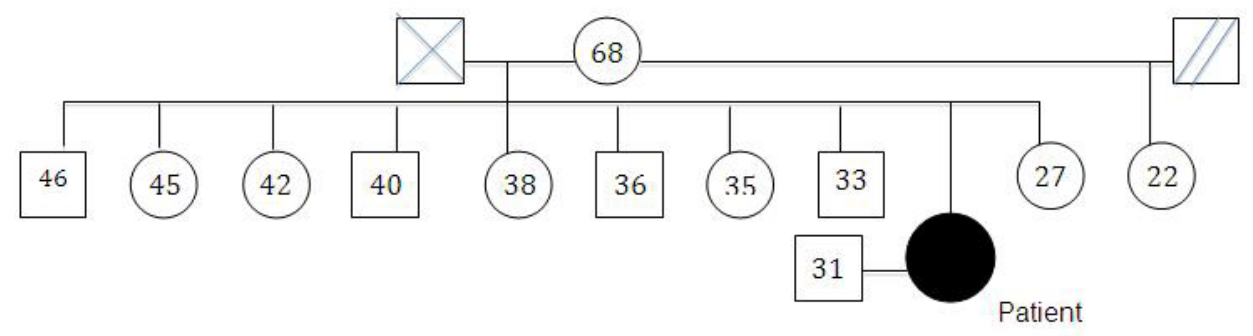

Figure 1: Family tree of the patient

70 years, when the patient was 6 years old, due to infection of the stomach. She claimed among sisters, she was the one who was closest to him. From what she could recall, she always spent time with her father. She described her father as very loving and nice person. Father never physically or sexually abused her. Her mother was a 68-year-old lady, still alive and healthy. Currently, she is staying with her youngest daughter. Patient described mother as a nice mother, not too strict but she was not so close with mother. She completed her primary and secondary education. She then further completed her study in Diploma in Accountancy at a public university, and subsequently further with Degree in Accountancy at the same University. She successfully graduated on time and got her job in the current workplace.

Physical examination and genital examination revealed normal findings. Mental examination revealed young Malay women within her 30's. She was been thin built with Body Mass Index (BMI) of $19 \mathrm{~kg} / \mathrm{m}^{2}$. She applied light make-up and appeared neat and tidy. She had satisfactory hygiene. She was noted to be depressed and anxious when talking about her sexual insufficiencies.

\section{DISCUSSION}

Vaginismus is probably one of the common sexual dysfunctions and its true prevalence among the general population is still unknown. This medical disorder significantly affects the quality of life and marital harmony (Frank et al. 1976). In our case, the lady presented with significant anxiety and depressive psychopathology that may further complicate her vaginismus as she was unable to perform the normal sexual intercourse activity. A specific therapy is needed to address her medical and psychological problem.

These therapies can help to address any underlying psychological issues, such as anxiety and combat any irrational or incorrect beliefs that one may have about sex and if necessary, be used to educate one about sex. Treatment like behavioural therapy may include systematic desensitization along with insertion of graded dilators/ fingers (McGuire \& Hawton 2003). The sex therapy sessions include sex education, homework assignment on certain sexual practice and cognitive therapy intervention in combination of relaxation therapy. Pharmacological interventions have included short term use of anxiolytics. There is 
limited evidence from case series and emperical sudies.

In the present case discussed, a biopsychosocial approach should be based on PLISST model (Annon 1976) involving sex education (permission and limited information), graded insertion of fingers (specific suggestions), Kegel's exercises and cognitive behavior therapy. The use of serotonin-selective reuptake inhibitors (SSRI) may aid the therapy if patients suffer from clinical depression. The successful approach towards managing vaginismus in a clinical setting, depends on many factors such as patient, partner and motivation.

\section{REFERENCES}

American Psychiatric Association. 2000. Diagnostic and Statistical Manual of Mental Disorders: DSM-IV. 4th edition. Text Revised. American Psychiatric Association: Washington, DC.

Annon, JS. 1976. The PLISSIT Model: A Proposed Conceptual Scheme for the Behavioral Treatment of Sexual Problems. Journal of Sex Education and Therapy 2(2): 1-15.

Ishak, W.W., Tobia, G. 2012. DSM-5 changes in diagnostic criteria of sexual dysfunctions. Reprod Syst Sex Disord 2: 122.

Frank, E., Anderson, C., Kupfer, D.J. 1976. Profiles of couples seeking sex therapy and marital therapy. Am J Psychiatry 133(5): 559-562.

McGuire, H., Hawton, K. 2003. Interventions for vaginismus. Cochrane Database Syst Rev (1): CD001760.

Reissing, E.D., Binik, Y.M, Khalife, S., Cohen, D., Amsel, R. 2004. Vaginal spasm, pain, and behavior: an empirical investigation of the diagnosis of vaginismus. Arch Sex Behav 33(1): 5-17. 